University of Windsor

Scholarship at UWindsor

\title{
PCB Food web dynamics quantify nutrient and energy flow in aquatic ecosystems
}

Anne M. McLeod

University of Windsor

Gord Paterson

State University of New York, Syracuse

Ken G. Drouillard

Douglas G. Haffner

University of Windsor

Follow this and additional works at: https://scholar.uwindsor.ca/glierpub

Part of the Biochemistry, Biophysics, and Structural Biology Commons, and the Physical Sciences and Mathematics Commons

\section{Recommended Citation}

McLeod, Anne M.; Paterson, Gord; Drouillard, Ken G.; and Haffner, Douglas G.. (2015). PCB Food web dynamics quantify nutrient and energy flow in aquatic ecosystems. Environmental Science and Technology, 49, 12832-12839.

https://scholar.uwindsor.ca/glierpub/15

This Article is brought to you for free and open access by the Great Lakes Institute for Environmental Research at Scholarship at UWindsor. It has been accepted for inclusion in Great Lakes Institute for Environmental Research Publications by an authorized administrator of Scholarship at UWindsor. For more information, please contact scholarship@uwindsor.ca. 


\section{PCB Food Web Dynamics Quantify Nutrient and}

\section{Energy Flow in Aquatic Ecosystems}

3 Anne M. McLeod ${ }^{1 *}$, Gordon Paterson ${ }^{2}$, Ken G. Drouillard ${ }^{l}$, G. Douglas Haffner ${ }^{l}$

$4 \quad{ }^{1}$ Great Lakes Institute for Environmental Research, University of Windsor, Ontario, Canada

$5 \quad$ N9B3P4.

$6 \quad{ }^{2}$ State University of New York, College of Environmental Science \& Forestry, Syracuse, New

7 York, USA, 13035

8 *Correspondence to: mcleod15@uwindsor.ca, (519) 253-3000 ext 3752, fax: 519-971-3616

9 KEYWORDS. Persistent Organic Pollutants as Chemical Tracers, Energy and Nutrient Flow,

10 Food webs, Lake Huron, Lake Trout.

11

12

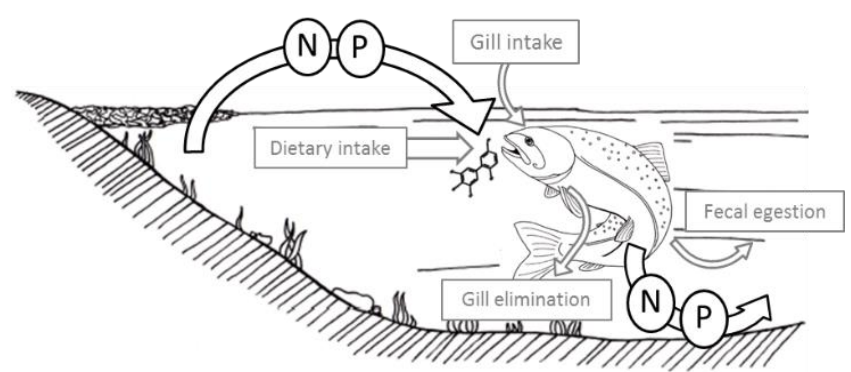

13 Accepted in Environmental Science and Technology, Oct. 2015. 
14 ABSTRACT. Measuring in situ nutrient and energy flows in spatially and temporally complex

15 aquatic ecosystems represents a major ecological challenge. Food web structure, energy and

16 nutrient budgets are difficult to measure, and it is becoming more important to quantify both

17 energy and nutrient flow to determine how food web processes and structure are being modified

18 by multiple stressors. We propose that polychlorinated biphenyl (PCB) congeners represent an

19 ideal tracer to quantify in situ energy and nutrient flow between trophic levels. Here, we

20 demonstrate how an understanding of PCB congener bioaccumulation dynamics provides

21 multiple direct measurements of energy and nutrient flow in aquatic food webs. To demonstrate

22 this novel approach, we quantified nitrogen $(\mathrm{N})$, phosphorus $(\mathrm{P})$ and caloric turnover rates for

23 Lake Huron lake trout, and reveal how these processes are regulated by both growth rate and fish

24 life history. Although minimal nutrient recycling was observed in young growing fish, slow

25 growing, older lake trout (> $5 \mathrm{yr}$ ) recycled an average of 482 Tonnes $\cdot \mathrm{yr}^{-1}$ of N, 45 Tonnes $\cdot \mathrm{yr}^{-1} \mathrm{of}$

$26 \mathrm{P}$ and assimilated $22 \mathrm{TJ} \mathrm{yr}^{-1}$ of energy. Compared to total $\mathrm{P}$ loading rates of $590 \mathrm{Tonnes}^{\mathrm{y}} \mathrm{yr}^{-1}$, the

27 recycling of primarily bioavailable nutrients by fish plays an important role regulating the

28 nutrient states of oligotrophic lakes.

Introduction:

31 Anthropogenic climate change, chemical pollution, nutrient loading, and habitat degradation are

32 some of the most critical factors simultaneously affecting aquatic ecosystems. These multiple

33 stressors can act synergistically resulting in a myriad of unpredictable responses causing aquatic

34 food webs to be irreparably altered. These perturbations are often enhanced by invasive species ${ }^{1}$

35 and can lead to declining fish abundances and condition, changes in reproductive success ${ }^{2}$, and

36 potentially lead to food web contractions and regime shifts ${ }^{3-4}$. While it is possible to estimate the 
37 effects of environmental and anthropogenic stressors on fish ecology and physiology $y^{5-8}$, as well

38 as identify changes in resource exploitation by fish through gut contents and stable isotope

39 analyses ${ }^{9-10}$, there are currently no methods to directly measure individual-based nutrient and

40 energy flows in food webs ${ }^{11}$. To achieve such measurements it is essential to be able to quantify

41 individual, in situ fish consumption rates.

43 Quantifying fish consumption rates is critical to understanding food web dynamics because fish

44 have been identified as both sinks ${ }^{12}$ and vectors of essential nutrients and energy transport ${ }^{13}$. Fish

45 communities play a critical role regulating the transport and fate of nutrients in aquatic

46 ecosystems as they are an important part of the overall nutrient pool ${ }^{12}$. Understanding nutrient

47 cycling and transport in biota is vital for predicting ecosystem responses to issues such as

48 eutrophication, species invasions and setting fisheries quotas.

50 The importance of quantifying fish consumption rates has long been recognized. Species-specific

51 bioenergetics models incorporating growth, metabolic and waste processes have been developed

52 for a suite of aquatic species, both juvenile and adult, starting with bluegills in $1974^{14}$. As of

532000 , papers being published a year on bioenergetics modeling have increased rapidly ${ }^{15}$. These

54 models rely on both laboratory and field data to estimate average consumption rates of different

55 age cohorts of fish ${ }^{16}$. Validations of bioenergetics models, however, generally tend to

56 demonstrate a poor fit between model predicted and lab or field data ${ }^{15}$. Thus, efforts to complete

57 hypothesis based testing of individual model parameters will serve to improve model structure

58 and performance ${ }^{15}$. Further, bioenergetics modelling efforts tend towards population based

59 predictions of predator demand rather than assessing individual based responses to ecosystem 
60 perturbations ${ }^{11,17}$. Similarly, the mass-balance approach is incorporated into Ecopath, Ecosim,

61 and Ecospace model estimates of consumption and trophic interactions ${ }^{18}$. Again, however, these

62 are population-wide estimates with a Bayesian resampling approach to estimating uncertainty ${ }^{18}$

63 without tracking individual responses within populations.

65 Chemical tracer mass balance approaches using Mercury and Cesium ${ }^{19,20}$ have also provided

66 alternative methods of calculating fish consumption rates. However, these approaches are limited

67 as singular metrics of dietary consumption and do not necessarily track similar environmental

68 processes. As food webs are temporally and spatially complex ${ }^{21}$, there is need for a method that

69 directly quantifies fish consumption rates and provides statistical power through multiple

70 repeatable metrics while tracking fish bioenergetics responses to environmental change.

72 This study proposes the use of persistent organic pollutants (POPs) as metrics to quantify

73 nutrient and energy flow within aquatic food webs. POPs, such as polychlorinated biphenyls

74 (PCBs), are globally ubiquitous pollutants that span a wide range of chemical hydrophobicities ${ }^{22}$

75 and many congeners are highly resistant to environmental and biological degradation ${ }^{23,24}$. These

76 chemical properties regulate their bioaccumulation in fish ${ }^{22}$, with the fraction of accumulation

77 from dietary versus aqueous sources ranging from $70 \%$ for less hydrophobic congeners (logKow

$78 \leq 6.5)$ to $100 \%$ for increasingly hydrophobic congeners ${ }^{25}$. Furthermore, elimination rates of the

79 more hydrophobic congeners (log Kow >6.5) are very low resulting in long chemical half-lives

80 with respect to the life span of fish ${ }^{26}$. Therefore, the body burden of super-hydrophobic

81 congeners (those with $\log \mathrm{K}_{\mathrm{OW}}>6.5$ ) represents a proxy of the total amount of food a fish has

82 consumed in its lifetime. Thus, the kinetics of PCB congeners in aquatic consumers have the 
83 potential to provide an in-situ repeatable method to quantify the total mass of food consumed

84 over the duration of a fish's life. Therefore persistent hydrophobic chemicals can be used as

85 multiple independent markers to directly measure nutrient and energy flow through the upper

86 trophic levels of food webs.

88 This study investigates (1) the use of PCB bioaccumulation dynamics to develop quantitative

89 measurements of both nutrient uptake and loss as well as the energy consumed over a fish's

90 lifespan as compared with previous model prediction methods, and, (2) quantify the relative

91 importance of fish for nutrient recycling in aquatic systems.

93 Experimental:

$94 \quad$ Sample Processing

95 Lake trout (Salvelinus namayacush; $\mathrm{n}=195)$, rainbow smelt (Osmerus mordax; $\mathrm{n}=34)$, round

96 goby (Neogobius melanostomus; $\mathrm{n}=27$ ), alewife (Alosa pseudoharengus; $\mathrm{n}=8$ ), and whitefish

97 species (Coregonus artedi and Coregonus hoyi; $\mathrm{n}=54$ ) were collected from the Canadian waters

98 of the Main Basin, Georgian Bay, and North Channel regions of Lake Huron throughout the

99 summers of 2010, 2011, and 2012. Fish were collected by overnight gill nets set by the Upper

100 Great Lakes Unit of the Ontario Ministry of Natural Resources. At each site a total of 18 nets

101 were set, and each net consisted of $15 \mathrm{~m}$ panel of $(32 \mathrm{~mm})$ mesh and a $25 \mathrm{~m}$ panel of $38 \mathrm{~mm}$ mesh

102 followed by 50m panels of 51, 64, 76, 89, 102, 114 and $127 \mathrm{~mm}$ meshes. Length and weight

103 measurements were taken, sex was determined, and otoliths and gut tracts removed, then samples 
104 were placed on dry ice. Frozen samples were transported back to the Great Lakes Institute for

105 Environmental Research (GLIER) and stored at $-25^{\circ} \mathrm{C}$ until processing.

106

107 Sample processing included homogenization of whole fish samples and the measurement of

108 whole body lipid contents. Moisture contents were obtained by drying approximately $0.5 \mathrm{~g}$ of

109 homogenate for 24 hours. Individual PCB congener concentrations and lipid contents were

110 determined using the microextraction method described by Daley et al. ${ }^{27}$ In brief, $0.5 \mathrm{~g}$ of whole

111 body homogenate was ground with $15 \mathrm{~g}$ of sodium sulfate using a glass mortar and pestle, and

112 then wet packed into a glass chromatography column containing $15 \mathrm{~mL}$ of a $50: 50$

113 hexane(Hex):Dichloromethane(DCM) $(v / v)$ extraction mixture, along with $35 \mathrm{ng}$ of a PCB 34

114 extraction performance recovery standard. After solvent elution, an additional $15 \mathrm{~mL}$ of

115 Hex:DCM was added to extract the homogenate. Sample extracts were then evaporated under

116 vacuum to $2 \mathrm{~mL}$, and then diluted to $10 \mathrm{~mL}$ with hexane in a volumetric flask. Neutral lipid

117 content was determined gravimetrically using $1 \mathrm{~mL}$ of this solution ${ }^{28}$. Six grams of Florisil

118 topped with approximately $1 \mathrm{~g}$ of sodium sulfate was then used for sample clean up with $50 \mathrm{~mL}$

119 hexane wash. The final extract was evaporated under vacuum to $<1 \mathrm{~mL}$ and brought to a final

120 volume of $1 \mathrm{~mL}$ with iso-octane for analysis by gas chromatography-electron capture detector

121 (GC-ECD) ${ }^{29}$. All samples were analyzed for the following PCB congeners (IUPAC \#): 18/19,

$12231 / 28,33,52,49,44,74,70,95,101,99,87,110,151 / 82,149,118,153,105 / 132,138,158$,

$123187,183,128,177,156 / 171,180,191,170,199,195 / 208,194,205,206$, and 209.

125 A method blank and an in house reference tissue homogenate of Detroit River carp were

126 extracted simultaneously as quality assurance for every set of 6 sample extractions. All sum PCB 
127 concentrations quantified in the reference tissue were in compliance with the Great Lakes

128 Institute for Environmental Research organic analytical laboratory's quality assurance guidelines

129 (mean \pm 2 standard deviations (SD)). Recoveries of the internal standard averaged $89 \% \pm 1 \%$

130 (Standard Error; $\mathrm{n}=195$ ), and sample concentrations were not recovery corrected.

132 Gut content analyses were performed using the Ontario Ministry of Natural Resources protocol.

133 Contents of the gut were removed and food items were identified by using calcified structures

134 such as otoliths that are generally resistant to digestion. Prey items were then enumerated and

135 species proportions calculated using the number of each prey item obtained.

\section{Consumption Estimates}

138 One of the major assumptions of the PCB approach proposed in this paper is that

139 biotransformation and depuration mechanisms do not contribute significantly to the whole body

140 elimination of the super hydrophobic congeners being used as food web tracers. All

141 metabolizable congeners were removed from the analyses to ensure no biotransformation was

142 occurring ${ }^{34}$. A review of literature estimates of elimination rates of PCB congeners by fish

143 demonstrated that congeners with a $\log \mathrm{K}_{\mathrm{OW}}$ greater than 6.5 did not demonstrate significant

144 elimination (see Fig. $1{ }^{35-40}$ ). Furthermore, the non-significant elimination rates for these

145 congeners resulted in a t95, $_{95}$ or time to steady state, vastly exceeding the life expectancy of the

146 organism. Therefore, the total body burden of any one of these super-hydrophobic congeners

147 represents an individual's lifetime of food consumption. 
148 Amounts of nitrogen and phosphorus recycled were calculated using the concentrations of PCB

149 congeners in the whole fish sample. First, concentration data were converted to mass values. The

150 amount of each PCB congener ingested was then calculated according to equation (1).

(1) Amount $P C B_{i}$ ingested $[n g]=m_{P C B_{i}} \times f_{P C B_{i}} \times\left(E_{d, P C B_{i}}\right)^{-1}$

152 where $\mathrm{PCB}_{\mathrm{i}}$ is the chosen $\mathrm{PCB}$ congener, $\mathrm{mPCB}_{\mathrm{i}}$ is the mass of $\mathrm{PCB}_{\mathrm{i}}$ in the consumer (in $n g$ ), $\mathrm{E}_{\mathrm{d}}$,

$153 \mathrm{PCB}_{\mathrm{i}}$ is the chemical assimilation efficiency for $\mathrm{PCB}_{\mathrm{i}}$ in food (prey), and $\mathrm{P}_{\mathrm{PCB}_{\mathrm{i}}}$ is the fraction of

$154 \mathrm{PCB}_{\mathrm{i}}$ mass which is accumulated through dietary uptake as opposed to gill intake (Table S1).

155 Using the results from the gut content analyses (Figure S2), the number of smelt, round goby and

156 other fish consumed were calculated according to equation (2)

157

(2) number of fish consumed $=\left(\frac{\text { Amount of } P C B_{i} \text { ingested }}{P C B_{i, p r e y}}\right) \times p_{\text {prey }}$

158 where amount of $\mathrm{PCB}_{\mathrm{i}}$ ingested is calculated using equation (1), $\mathrm{PCB}_{\mathrm{i}}$, prey is the average mass

159 (ng) of $\mathrm{PCB}_{\mathrm{i}}$ in the prey species (smelt, round goby, or other), and prey is the proportion of diet

160 made up of that prey species (where proportion of smelt, round goby, and other fish consumed

161 by lake trout were, respectively, 0.88, 0.075, and 0.045 for the Main Basin of Lake Huron, 0.77,

162 0.1, and 0.13 for the Georgian Bay, and 0.98, 0.015, and 0.005 for the North Channel).

163 Consumption estimates were then compared to consumption estimates presented in Stewart et

164 al. ${ }^{16}$ and Pazzia et al. ${ }^{20}$ by extrapolating their estimates to include 13 year old fish using the

165 equations provided in their work.

166

167 Nitrogen and Phosphorus Recycling Estimates

168 Determination of nitrogen content was conducted in the Chemical Tracers laboratory at GLIER

169 using a continuous-flow isotope ratio mass spectrometer (Finnigan MAT Deltaplus; Thermo 
170 Finnigan, San Jose, California) on freeze dried homogenates (Labconco co., Kansas City Missouri)

171 which had been ground using mortar and pestle, and then lipid extracted using chloroform-

172 methanol $^{29}$.

173

174 Total mg of nitrogen was subsequently calculated from dry weight (g) according to equations 3

175 and 4.

176

(3) Dry weight $[g](d w)=w w-w w\left(\frac{\text { \%moisture }}{100}\right)$

177

(4) $N[m g]=\left(\left(\frac{\% N}{100}\right) \times d w\right) \times 1000$

178 where ww is the wet weight of the fish. The amount of phosphorus was then estimated using the

179 P:N ratio of 1:10.6 for wild caught fish ${ }^{30}$. Total calories in each diet item were calculated using

180 fish energy densities ${ }^{31}$.

181

182 Using the calculated mass of $\mathrm{N}$, the total amount of $\mathrm{N}$ ingested by each lake trout was

183 determined according to equation 5.

184

(5) $N$ ingested $[m g]=\sum N_{\text {prey }} \times$ number of fish consumed $p r e y$

185 where $\mathrm{N}_{\text {prey }}$ is the average amount of nitrogen $(\mathrm{mg})$ in the prey fish calculated using equation (4),

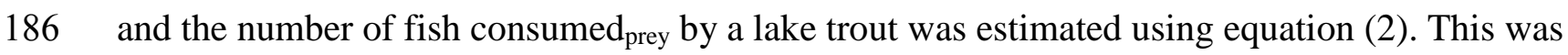

187 then summed across all prey species. Both $\mathrm{P}$ and calories ingested were calculated in a similar

188 manner, where $\mathrm{P}(\mathrm{mg})_{\text {prey }}$ was estimated using a P:N ratio of $1: 10.6^{30}$, and calories in prey fish

189 were calculated using energy densities ${ }^{2}$. Finally, mass of $\mathrm{N}$ recycled was calculated according to

190 equation 6.

$191 \quad$ (6) $N$ recycled $[\mathrm{mg}]=N_{\text {ingested }}-N_{\text {lake }}$ trout 
192 where $\mathrm{N}_{\text {lake trout }}(\mathrm{mg})$ was calculated using equation (4), and $\mathrm{N}_{\text {ingested }}(\mathrm{mg}$ ) was calculated using

193 equation (5). The mass of $\mathrm{P}$ recycled was calculated in a similar manner.

195 Data analysis

196 Growth rates of Lake Huron lake trout were calculated using the von Bertalanffy (VBL) growth 197 rate model comparing total length and age (equation 7)

(7) $\quad L_{t}=L_{\infty}\left(1-e^{-k\left(t-t_{0}\right)}\right)$

201 where $t$ is lake trout age $(\mathrm{yr}), L_{t}$ is the total length $(\mathrm{cm})$ of the fish at time $t, L_{\infty}$ is the asymptotic

202 length $(\mathrm{cm})$, and $k$ the growth coefficient $\left(\mathrm{yr}^{-1}\right)$. The model was calculated using a value of $t_{0}=0$, 203 for the theoretical age at a total length of 0 , an assumption validated for whitefish ${ }^{32}$, another 204 salmonid, and used for lake trout ${ }^{33}$. Calculations of the VBL growth models were done using the 205 non-linear regression module of SYSTAT (SYSTAT 11). Multiple iterations were done to 206 achieve optimal model fit. The square of the correlation coefficients between observed and 207 predicted values were used to calculate the coefficient of determination $\left(r^{2}\right)$ values for the VBL 208 growth models. Individual growth rates $\left(\% \cdot\right.$ year $\left.^{-1}\right)$ were obtained by equation 8 .

210 (8) Growth rate $\left(\% \cdot\right.$ year $\left.{ }^{-1}\right)=\left(\frac{w}{w_{t}}\right) \times \ln \left(\frac{w_{t}}{w_{t+1}}\right) \times 100$

211 where $w$ is the measured weight of the individual, $w_{\mathrm{t}}$ the von Bertalanffy predicted weight at age

$212 t$, and $w_{\mathrm{t}+1}$ the von Bertalanffy predicted weight at age $t+1$. 


\section{Results \& Discussion:}

215 A unique aspect of using PCBs as markers of individual consumption rates is their potential to

216 offer multiple, repeatable metrics for calculating consumption dynamics in individual fish. To

217 demonstrate the power of the PCB approach, we used an ANOVA to compare congener-specific

218 consumption estimates for the 15 most abundant congeners and found no significant differences

219 among the 9 congeners with $\log K_{\mathrm{ow}}>6.5(\mathrm{p}>0.15)$. This lack of significant differences

220 demonstrates that the measured consumption rates are not chemical dependent, hence any of

221 these highly hydrophobic congeners represent tracers of prey consumption. For our purposes, we

222 chose PCB 153, a highly recalciatrant and ubiquitous PCB congener that is commonly monitored

223 in trophic magnification studies ${ }^{41,42}$, as well as other contaminant ecology studies ${ }^{43,44}$. Moreover,

224 the similar variability among the congeners further demonstrates that each congener is tracking

225 common bioaccumulation processes (Figure 2). This correspondence in individual variability and

226 bioaccumulation rates among congeners confirms that super-hydrophobic PCB congeners offer

227 multiple, repeatable metrics for calculating consumption dynamics in fish.

229 Quantifying the consumption rates of top predator in aquatic ecosystems is essential for

230 understanding pollutant and nutrient trophodynamics and multiple approaches have been

231 developed to generate such consumption estimates. For instance, bioenergetics studies have used

232 sub-models of physiological characteristics such as metabolism, growth, excretion, and

233 reproduction to develop consumption estimates for age cohorts within a population ${ }^{14,16,45}$, while

234 more empirical approaches have used Mercury $(\mathrm{Hg})$ and Cesium-137 $\left({ }^{137} \mathrm{Cs}\right)$ dynamics ${ }^{19,20}$.

235 Figure 3 compares fish consumption estimates using the PCB 153 method presented here with

236 estimates modeled by Stewart et al. ${ }^{16}$ for Lake Michigan lake trout, and by ${ }^{137}$ Cs estimates 
237 observed by Pazzia et al. ${ }^{20}$ for Lake Ontario lake trout. Calculations of maximum consumption $238\left(\mathrm{C}_{\max }\right)$ provided in Stewart et al. ${ }^{16}$ are also included in Figure 3 using temperature and weight

239 data obtained from the present study. As observed in Figure 3, the PCB model developed in the 240 current study provides consumption estimates below those of $\mathrm{C}_{\max }$, and similar to those obtained

241 or estimated from the other studies or models. The PCB method, however, provides direct

242 measurement of individual-based consumption, using concentrations observed in individual fish.

243 As Figure 3 demonstrates, there is considerable individual variability in consumption within a

244 population and the PCB method offers greater resolution as to the causes of these individual-

245 level differences.

247 The PCB method not only provides a way of calculating individual consumption estimates, but 248 provides a foundation for estimating nitrogen and phosphorus recycling by individual organisms.

249 Estimates of the lifetime nitrogen $(\mathrm{N})$ and phosphorus $(\mathrm{P})$ recycled by lake trout (Salvelinus

250 namaycush) based on PCB 153 accumulation dynamics revealed a power relationship, where the

251 mass of $\mathrm{N}$ and $\mathrm{P}$ recycled by fish increased with age (Figure 4). As the fish reached the

252 maximum asymptotic length predicted by the von Bertalanffy (VBL) growth model, the mass of 253 recycled nutrients increased exponentially. Specifically, as growth rates slow to this asymptote,

254 the majority of consumed prey energy and nutrients will be turned over via metabolic respiration 255 rather than assimilated into new somatic growth. Therefore these older individuals become 256 increasingly important sources of nutrient recycling. The relationship between nutrient recycling 257 and fish age and size is further resolved by examining fish growth rates. Individual growth rates $258\left(\% \cdot\right.$ year $\left.^{-1}\right)$ as a function of fish age (Figure $\left.4, d\right)$, indicates that lake trout $\geq 5$ years of age had 259 individual growth rates below $50 \% \mathrm{yr}^{-1}$. At this time in their life history, these upper age cohorts 
260 become nutrient sources through recycling rather than net nutrient sinks. The importance of older

261 fish regarding nutrient recycling increases exponentially as their growth rates continue to

262 decrease with age.

263

264 In one year, a single 13 year old lake trout from Lake Huron will have consumed 65 MJ of

265 energy and will have recycled $1441 \mathrm{~g}$ of $\mathrm{N}$ and $136 \mathrm{~g}$ of $\mathrm{P}$. If fish population age structure

266 estimates are made using the yearly stocking levels of $4.3 \times 10^{6}$ yearlings with $40 \%$

267 mortalities/year ${ }^{46}$ and assuming a simple exponential decay model, then over a one year period,

268 in total, the lake trout population between 5 and 13 years of age (estimated at $1.7 \times 10^{6}$

269 individuals; capped at 13 as that is the oldest fish captured in the study) will have recycled 482

270 Tonnes of N, 45 Tonnes of $\mathrm{P}$, and have acquired $22 \mathrm{TJ}$ of energy. This compares to zebra

271 (Dreissena polymorpha) and quagga (Dreissena bugensis) mussels that are estimated to divert up

272 to 20 Tonnes of P in Lake Huron's Saginaw Bay region and are also associated with the near-

273 shore shunt in Great Lakes ecosystems ${ }^{47}$. Total annual P loads to Lake Huron are estimated to be

274590 Tonnes and the results of our study indicate that lake trout can recycle up to $7.6 \%$ of this

275 total load. However, it must be emphasized that much of the phosphorus recycled by fish will be

276 in bioavailable form and thus capable of directly supporting a significant proportion of primary

277 production in the lake ${ }^{48}$. Furthermore, nutrient recycling by other fish species will increase this

278 estimate.

279

280 Although the impact of fish as a phosphorus sink has been previously documented ${ }^{12}$, their

281 importance as nutrient recycling sources has been highly disputed. It is recognized that

282 anadromous species, such as Pacific salmon (Oncorhynchus spp), are important sources of 
283 nutrients in coastal freshwater communities, acting as biovectors, transporting nutrients

284 accumulated in the marine environment to coastal freshwater systems ${ }^{49,50}$. Studies of larger,

285 piscivorous fish have noted their importance as potential nutrient sources ${ }^{51,52}$ whilst others

286 examining smaller, forage fish argue to the contrary ${ }^{53}$. Previous nutrient studies relied on

287 bioenergetics modeling and population density and growth estimates to estimate the relative

288 importance of fish on nutrient recycling in aquatic ecosystems ${ }^{14,17}$. The PCB method developed

289 in the current study provides a novel approach to quantify in situ the magnitude of nutrient

290 recycling achieved by fish using multiple, repeatable metrics. In this capacity, top predator

291 species such as lake trout can act as off-shore vectors of these limiting nutrients thereby reducing

292 the impact of the near shore shunt phenomenon as associated with dreissenid mussel

293 establishment ${ }^{47}$.

295 The life history of other large piscivores, however, can prevent these top predators from acting as

296 off-shore nutrient shunts. For instance, Lake Huron is also stocked with Pacific salmonids

297 (Onchorhynchus spp) which, in contrast to lake trout, grow more rapidly, have shorter life spans

298 and migrate to tributaries and streams at maturity where they spawn and die $e^{54-56}$. This specific

299 reproductive ecology has garnered Pacific salmonids much attention as sources of nutrients and

300 contaminants in spawning tributaries ${ }^{57-61}$. Pacific salmonid spawning migrations generally occur

301 only when individual growth rates decline below $50 \%$ per year. These older salmon provide

302 limited contributions to offshore nutrient recycling with the mature senescent individuals

303 exporting a significant mass of nutrients out of the lake ${ }^{61}$. These observations highlight the

304 importance of piscivore life history with respect to nutrient transportation and export in aquatic

305 ecosystems. 
307 While multiple factors have been identified as contributing to the regime shift in Lake Huron ${ }^{62}$,

308 there is general agreement the lake is showing definite signs of 'oligotrophication'. The results of

309 this study indicate that older lake trout can play an important role in the nutrient recycling in

310 oligotrophic lakes, systems to which they have well-adapted life histories. The stocking of fish

311 like salmon, however, is predicted to contribute significantly to a decline in bioavailable

312 nutrients, especially in the pelagic compartment. In Lake Huron, however, Pacific salmonid

313 abundances have declined dramatically following the collapse of alewife stocks ${ }^{46}$ and older (> 5

$314 \mathrm{yrs})$ lake trout have become the predominant off-shore salmonid predator population in the

315 lake $^{63}$. Given the differing life-spans, growth rates and reproductive strategies of lake trout

316 relative to stocked Pacific salmonids in the Great Lakes ${ }^{54}$, the results of this study demonstrate

317 that lake trout provide a critical ecosystem service by effectively recycling offshore nutrients to

318 enhance food web stability and productivity in highly oligotrophic ecosystems.

320 Most importantly, this study demonstrates that PCB congeners can be used to quantify in situ

321 nutrient and energy flow in aquatic systems. Through the use of this metric, we have been able to

322 demonstrate the importance of fish growth rates and life history on the recycling of essential

323 limiting nutrients in oligotrophic lakes. The ubiquitous nature of PCBs implies that this

324 technique is applicable to aquatic systems across the globe. Moreover, due to the presence of

325 different congeners, PCBs provide repeatable, independent metrics for measuring nutrient and

326 energy flow which will allow us to quantify the effects of multiple environmental and

327 anthropogenic stressors across different aquatic ecosystems. 


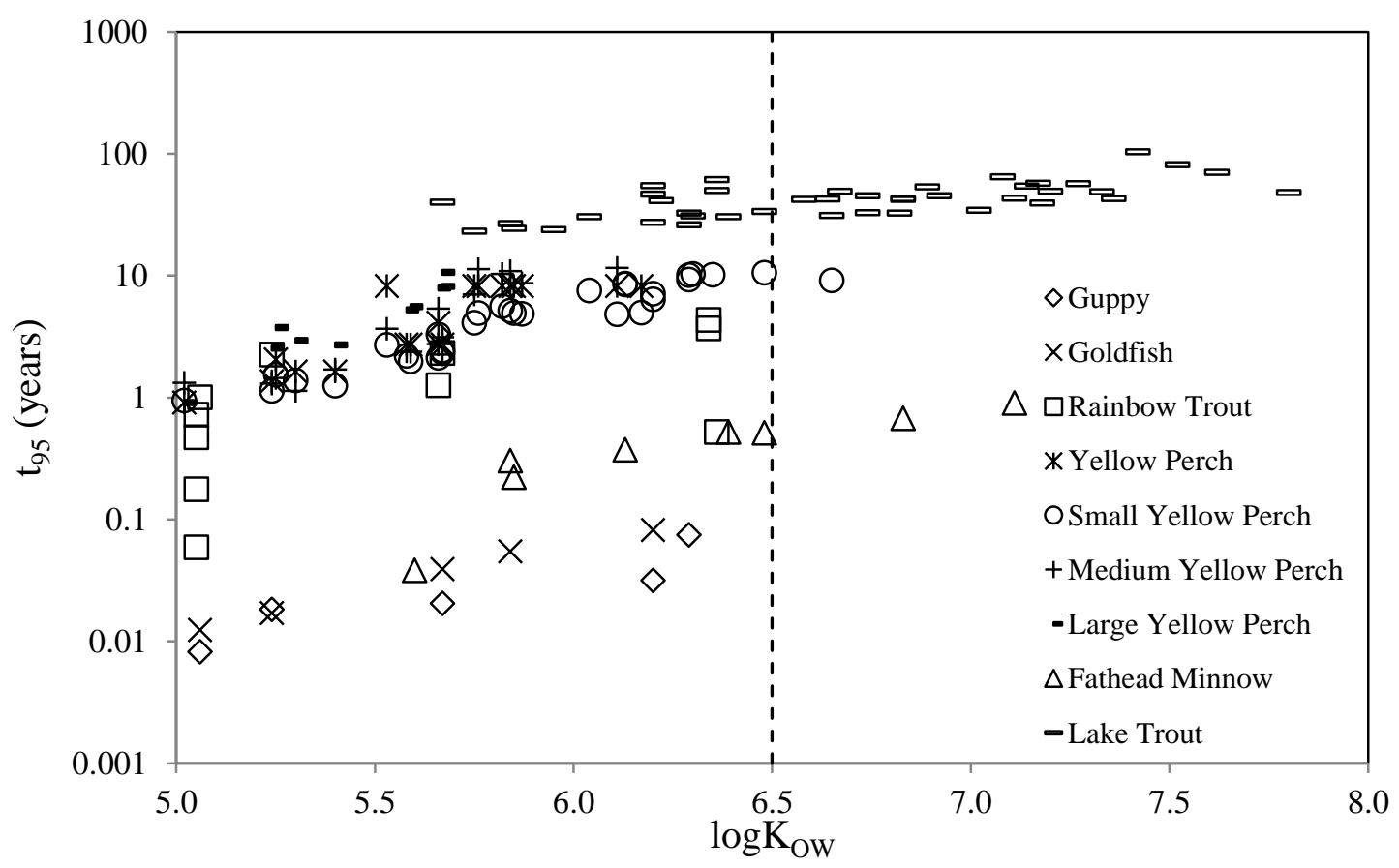

331 Figure 1: Literature $t_{95}$ estimates across a range of log Kows. Only those congeners depicting

332 significant elimination are shown ${ }^{35-40}$. The dashed line represents the cut off at a log Kow of 6.5,

333 after which very few studies revealed significant elimination of congeners and these congeners

334 were only in small fish. All estimates presented here are measured t95 estimates, with the

335 exception of lake trout which were modeled; hence the elimination rates may not have been

336 significant. However, the elimination rate estimates demonstrate that it takes at least a hundred

337 years for congeners with higher log Kows to reach steady state. 


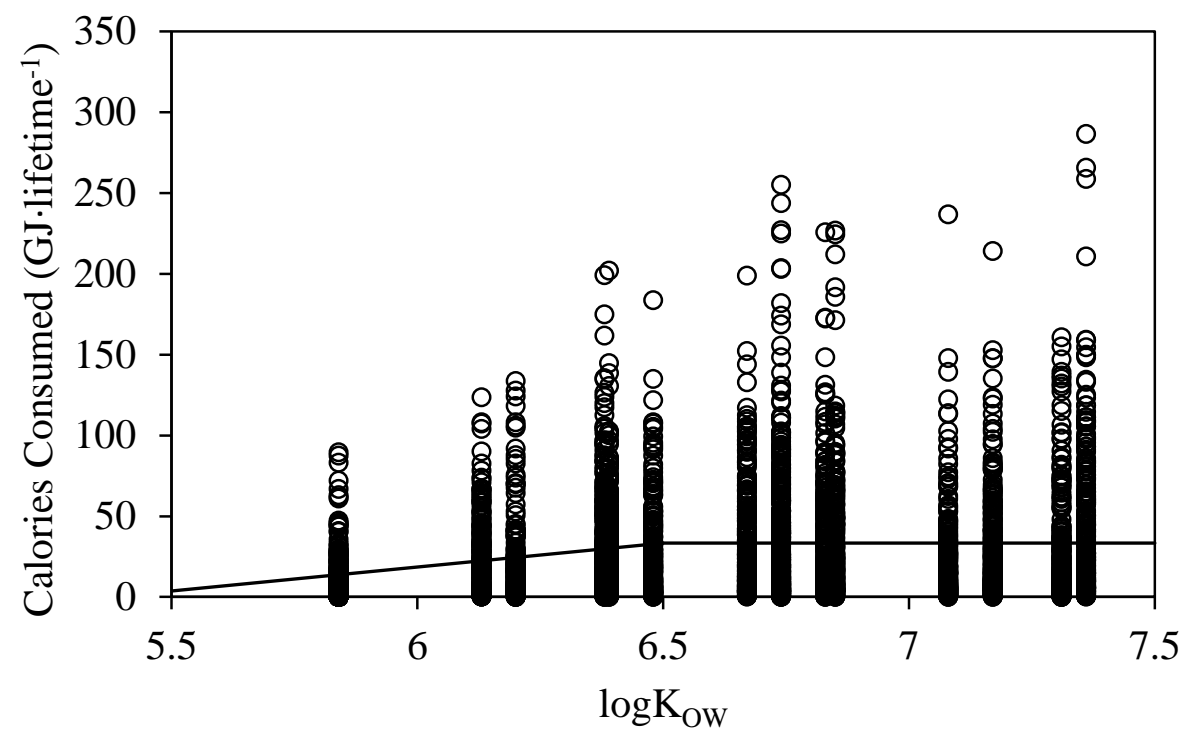

339

340 Figure 2. The relationship between calories consumed and $\log \mathrm{K}_{\mathrm{OW}}$ for the 15 most abundant

341 PCB congeners (PCBs 52, 70, 95, 99, 101, 110, 118, 128, 138, 149, 153, 170, 177, 180, 187).

342 Piece-wise linear regressions were completed and no significant slope was found for congeners

343 with $\log \mathrm{K}_{\mathrm{OW}}>6.5$. 


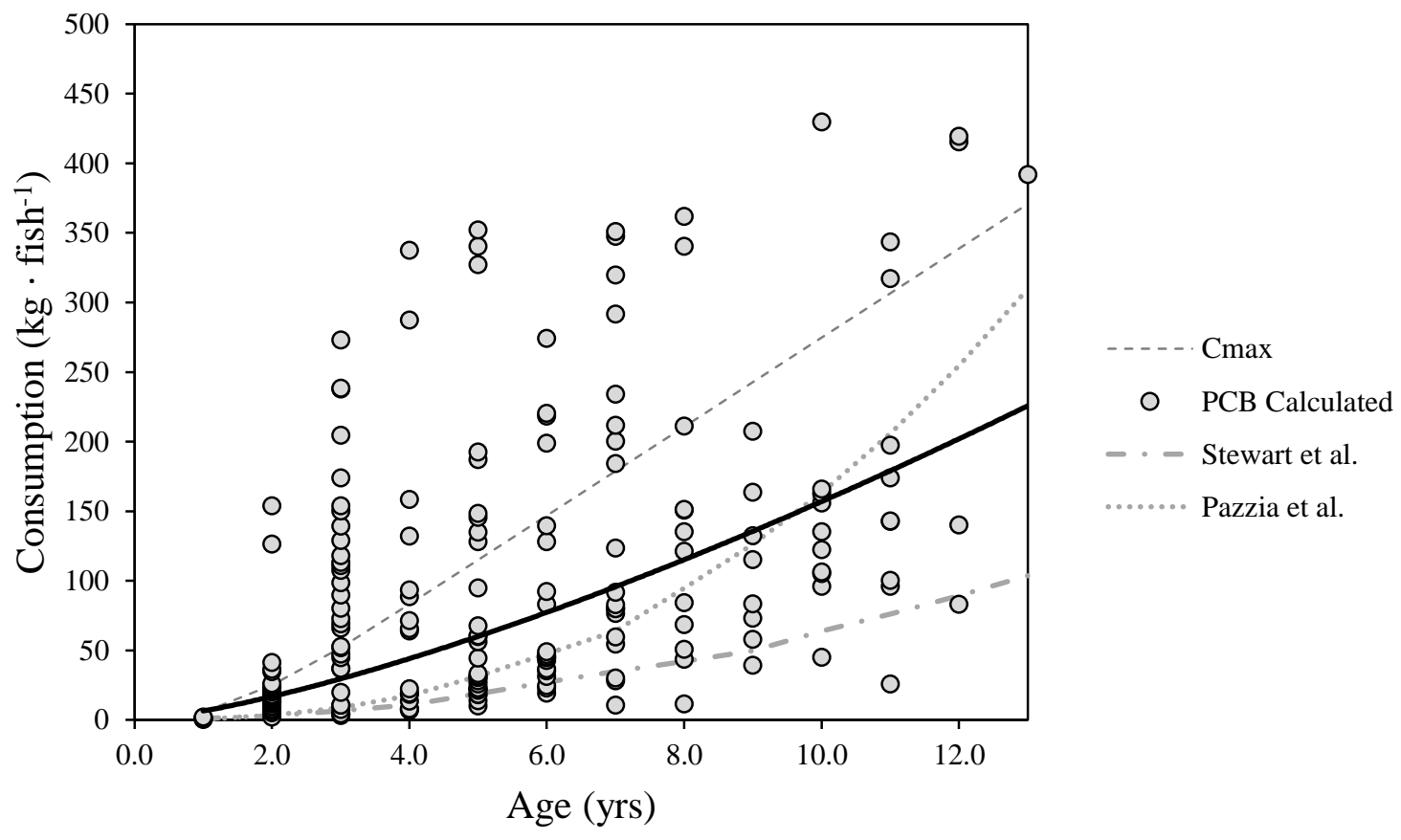

347 Figure 3: Lifetime prey consumption estimates $\left(\mathrm{kg} \cdot \mathrm{fish}^{-1}\right)$ for lake trout calculated using PCB

348153 (grey circles, solid black line of best fit; $y=6462.8 x^{1.4} R^{2}=0.4$ ), using $C_{\max }$ equation

349 (dashed dark grey line) provided in Stewart et al. $1983^{16}$, with temperature and weight values

350 obtained from our study, from extrapolation of bioenergetics estimates by Stewart et al. $1983^{16}$

351 for Lake Michigan lake trout (dashed-dotted dark grey line), and from extrapolation of ${ }^{137} \mathrm{Cs}$

352 estimates for Lake Ontario lake trout by Pazzia et al. $2002^{20}$ (dotted grey line). 

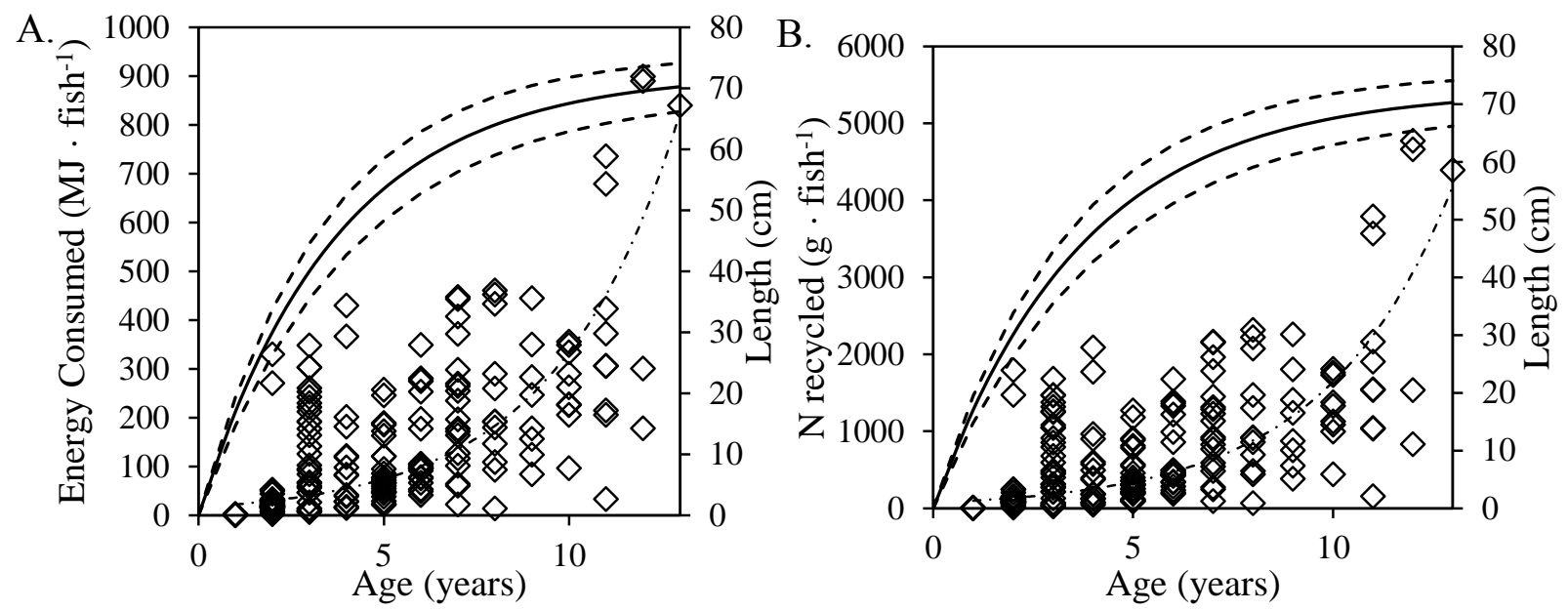

355

C.

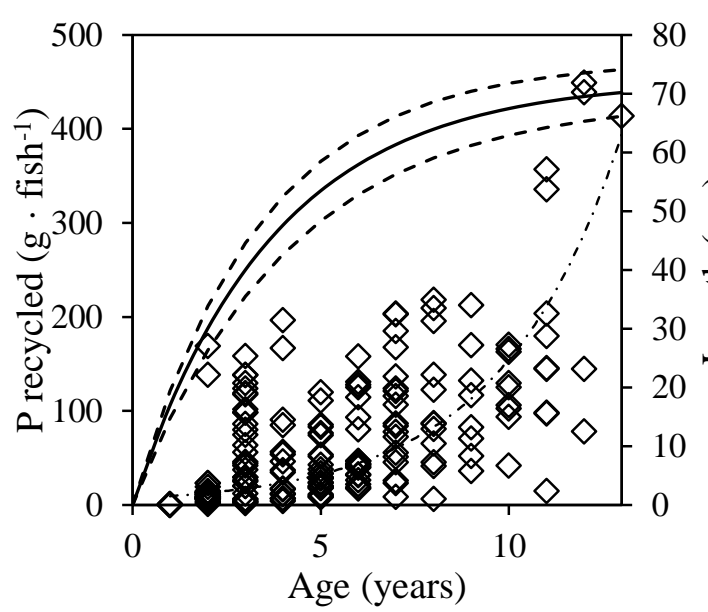

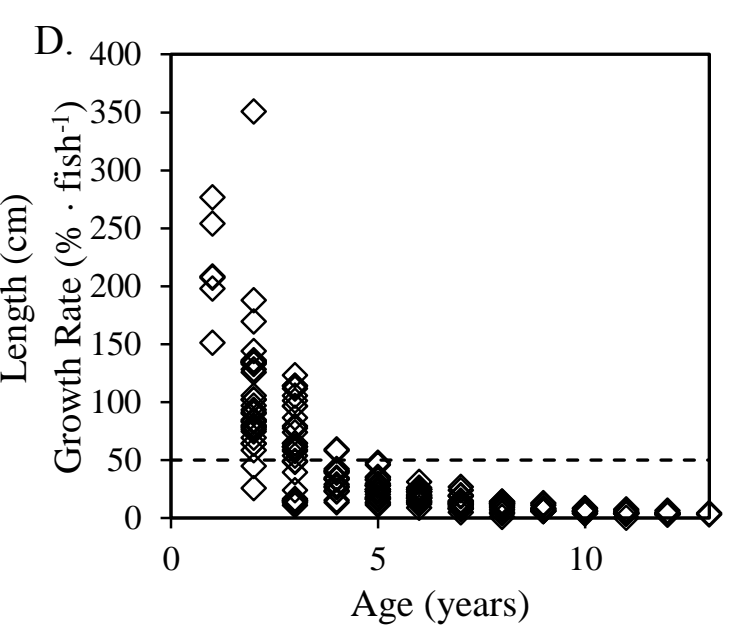

358 Figure 4: (A-C) Relationships between the amount of (A) energy consumed (MJ · fish) and (B)

359 nitrogen and (C) phosphorus recycled ( $\mathrm{g} \cdot \mathrm{fish})$ by lake trout. The solid curve in panels A-C

360 represents the von Bertalanffy growth curve for lake trout with dotted lines representing the $95 \%$

361 confidence intervals. The dashed line in panels A-C represent the best fit, non-linear regression $\left(y=16.625 \mathrm{e}^{0.3003 x}, R^{2}=0.42\right)$ and $N\left(y=72.339 \mathrm{e}^{0.3122 x}, R^{2}=0.40\right)$ and $P\left(y=6.8181 e^{0.3122 x}, R^{2}=\right.$ 
363 0.40). Panel D provides the relationship between individual lake trout growth rate $\left(\%\right.$ year $\left.^{-1}\right)$ and 364 age with the dashed line indicating a growth rate of $50 \%$ year $^{-1}$.

365

366 ASSOCIATED CONTENT

367 Supporting Information.

368 Values for congener $\log \mathrm{K}_{\mathrm{OW}}{ }^{22}, \mathrm{E}_{\mathrm{d}, \mathrm{PCBi}}{ }^{26}$ and $\mathrm{f}_{\mathrm{PCBi}}{ }^{25}$ used in the calculations of the amount of $\mathrm{PCB}_{\mathrm{i}}$

369 ingested by a fish, results from gut content analyses on Lake Trout. This material is available free

370 of charge via the Internet at http://pubs.acs.org.

371 AUTHOR INFORMATION

372 Corresponding Author

373 Great Lakes Institute for Environmental Research, University of Windsor, Ontario, Canada

374 N9B3P4. Correspondence to: mcleod15@uwindsor.ca, (519) 253-3000 ext 3752.

\section{Author Contributions}

376 G.D.H., G.P., and A.M. initiated the study, while K.G.D. provided input on development of the

377 modeling component. All authors were involved in the writing of the paper, but the main

378 contributions were by A.M. All authors discussed the results and consulted on the paper.

\section{Funding Sources}

380 Funding was supported by NSERC and CRC grants to GDH.

381

382 ACKNOWLEDGMENT 
This research was supported by the Ontario Ministry of Natural Resources Upper Great Lakes

384 Management Group who provided ship time and assisted with the ageing and diets of fish. ABBREVIATIONS

386 PCB, polychlorinated biphenyl; N, nitrogen; P, phosphorus; POPs, persistent organic pollutants;

387 Kow, octanol-water partition coefficient; Hex, hexane; DCM, dichloromethane; VBL, von

388 Bertalanffy Growth; dw, dry weight, $\mathrm{m}_{\mathrm{PCBi}}$, the mass of $\mathrm{PCB}_{\mathrm{i}}$ in the fish (in ng); $\mathrm{E}_{\mathrm{d}, \mathrm{PCBi}}$,

389 the organism's chemical assimilation efficiency for food for $\mathrm{PCB}_{\mathrm{i}}$; $\mathrm{f}_{\mathrm{PCB}}$, the fraction of $\mathrm{PCB}_{\mathrm{i}}$

390 mass which is accumulated through ingestion; $t$, lake trout age $(\mathrm{yr}) ; \mathrm{L}_{\mathrm{t}}$, the total length $(\mathrm{cm})$ of

391 the fish at time $t ; L_{\infty}$, the asymptotic length $(\mathrm{cm}) ; \mathrm{k}$, the growth coefficient $\left(\mathrm{yr}^{-1}\right)$.

392

393

394

395

396

397

398

399

400

401

402

403

404

\section{REFERENCES}

1. Riley, S. C.; Roseman, E. F.; Nichols, S. J.; O’Brien, T. P.; Kiley, C. S.; Schaeffer, J. S. Deepwater demersal fish community collapse in Lake Huron. Trans. Am. Fish. Soc. 2008, 137(6), 1879-1890, DOI 10.1577/T07-141.1.

2. Paterson, G.; Hebert, C. E.; Drouillard, K. G.; Haffner, G. D. Congruent energy density trends of fish and birds reflect ecosystem change. Limnol. Oceanogr. 2014, 59 (4), 11711180, DOI 10.4319/lo.2014.59.4.1171.

3. Madenjian CP; Rutherford CS; Stow CA; Roseman EF; He JX. Trophic shift, not collapse. Environ Sci Technol, 2013, 47(21) 11915-11916, DOI 10.1021/es404089y

4. Ridgway MS. Seasonal and annual patterns in density of double-crested cormorants in two coastal regions of Lake Huron. J Gt Lakes Res, 2010, 36(3), 411-418, DOI 10.1016/j.jglr.2010.05.010 
5. Waser W.; Sahoo, T. P.; Herczeg, G.; Merila, J.; Nikinmaa, M. Physiological differentiation among nine-spined stickleback populations: Effects of copper exposure. Aquat. Toxicol. 2010, 98 (2), 188-195; DOI 10.1016/j.aquatox.2010.02.009.

6. MacFadyen, E.J.; Williamson, C. E.; Grad, G.; Lowery, M.; Jeffrey, W.H.; Mitchell, D. L. Molecular response to climate change: temperature dependence of UV-induced DNA damage and repair in the freshwater crustacean Daphnia pulicaria. Global Change Biol. 2004, 10 (4), 408-416; DOI 10.1111/j.1529-8817.2003.00750.x

7. Davoren, G. (2013) Distribution of marine predator hotspots explained by persistent areas of prey. Mar. Biol. 2013, 160 (12), 3043-3058; DOI 10.1007/s00227-013-2294-5

8. Aurelio, M.; Faleiro, F.; Lopes, V. M.; Pires, V.; Lopes, A. R.; Pimentel, M. S.; Repolho, T.; Baptista, M.; Narciso, L.; Rosa, R. Physiological and behavioural responses of temperate seahorses (Hippocampus guttulatus) to environmental warming. Mar. Biol. 2013, 160 (10), 2663-2670; DOI 10.1007/s00227-013-2259-8.

9. Corrigan, L.J.; Winfield, I. J.; Hoelzel, A. R.; Lucas, M. C. Dietary plasticity in Arctic charr (Salvelinus alpinus) in response to long-term environmental change. Ecol. Freshwater Fish. 2011, 20 (1), 5-13; DOI 10.1111/j.1600-0633.2010.00446.x Dallai, L. Stable isotopes reveal Holocene changes in the diet of Adélie penguins in Northern Victoria Land (Ross Sea, Antarctica). Oecologia. 2011, 164 (4), 911-919; DOI 10.1007/s00442-010-1790-2.

11. McCann K. Protecting biostructure. Nature. 2007, 226 (7131), 29; DOI $10.1038 / 446029 a$. 
12. Sereda, J. M.; Hudson, J. J.; Taylor, W. D.; Demers, E. Fish as sources and sinks of nutrients in lakes. Freshwater Biol. 2007, 53 (2), 278-289; DOI 10.1111/j.13652427.2007.01891.x.

13. Moore, J. W.; Schindler, D.E.; Carter, J.L.; Fox, J.; Griffiths, J.; Holtgrieve, G.W. Biotic control of stream fluxes: Spawning salmon drive nutrient and matter export. Ecology

14. Kitchell, J.F.; Koonce, J.F.; Magnuson, J.J.; O'Neill, R.V.; Shugart Jr, H.H.; Booth, R.S. Model of fish biomass dynamics. Trans. Am. Fish. Soc. 1974, 103 (4), 786-798; DOI: 10.1577/1548-8659(1974)103'786:MOFBD.2.0.CO;2.

15. Chipps, S.R.; Wahl, D.H. Bioenergetics modeling in the $21^{\text {st }}$ Century: Reviewing new 2007, 88 (5), 1278-1291; DOI 10.1890/06-0782

insights and revisiting old constraints. Trans. Am. Fish. Soc. 2008, 137 (1), 298-313; DOI: $10.1577 / \mathrm{T} 05-236.1$

16. Stewart, D.J.; Weininger, D.; Rottiers, R.V.; Edsall, T.A. An energetics model for Lake Trout, Salvelinus namaycush: Application to the Lake Michigan population. Can. J. Fish. Aq. Sci. 1983, 40 (6), 681-698; DOI: 10.1139/f83-091.

17. Kraft C. Estimates of phosphorus and nitrogen cycling by fish using a bioenergetics approach. Can. J. Fish. Aquat. Sci. 1992, 49 (12), 2596-2604; DOI 10.1139/f92-287.

18. Pauly, D.; Christensen, V; Walters, C. Ecopath, Ecosim, and Ecospace as tools for evaluating ecosystem impacts of fisheries. J. of Marine Sci. 2000, 57(3), 697-706; DOI: 10.1006/imsc.2000.0726.

19. Trudel, M.; Tremblay, A.; Schetagne, R.; Rasmussen, J.B. Estimating food consumption rates of fish using a mercury mass balance model. Can. J. Fish Aq. Sci. 2000, 57(2), 414428; DOI: $10.1139 / \mathrm{f99}-262$. 
20. Pazzia, I.; Trudel, M.; Ridgway, M.; Rasmussen, J.B. Influence of food web structure on the growth and bioenergetics of lake trout (Salvelinus namaycush). Can. J. Fish. Aq. Sci. 2002, 59 (10) 1593-1605; DOI: 10.1139/f02-128.

21. Abma, R.A.; Paterson, G.; McLeod, A.; Haffner, G.D. Cross-basin comparison of mercury bioaccumulation in Lake Huron lake trout emphasizes ecological characteristics. Environ. Toxicol. Chem. 34 (2); 355-359, DOI: 10.1002/etc.2810.

22. Hawker, D. W.; Connell, D. W. Octanol-water partition coefficients of polychlorinated biphenyl congeners. Environ. Sci Technol. 1988, 22 (4), 382-387; DOI $10.1021 / \mathrm{es} 00169 \mathrm{a} 004$

23. Atlas, E.; Bidleman, T.; Giam, C. S. Atmospheric transport of PCB to the oceans. In PCBs and the environment; Waid J. S., Eds.; CRC Press: Boca Raton 1986: pp 79-100

24. Tanabe, S.; Tatsukawa, R. Distribution, behavior and load of PCBs in the oceans. In PCBs and the environment, Waid J. S., Eds.; CRC Press: Boca Raton 1986: pp 143-161

25. Arnot, J. A.; Gobas, F. A. P. C. Food web bioaccumulation model for organic chemicals in aquatic ecosystems. Environ. Toxicol. Chem. 2004, 23 (10), 2343-2355, DOI $10.1897 / 03-438$.

26. Liu, J.; Haffner, G. D.; Drouillard, K. G. The influence of diet on the assimilation efficiency of 47 polychlorinated biphenyl congeners in Japanese koi (Cyprinus carpio). Environ. Toxicol. Chem. 2009, 29 (2), 401-409, DOI 10.1002/etc.47. polychlorinated biphenyl (PCB) congeners in yellow perch (Perca flavescens) eggs during incubation. Chemosphere. 2009, 75 (11), 1500-1505, DOI 10.1016/j.chemosphere.2009.02.013. 
28. Drouillard, K. G.; Hagen, H.; Haffner, G. D. Evaluation of chloroform/methanol and dichloromethane/hexane extractable lipids as surrogate measures of sample partition capacity for organochlorines in fish tissues. Chemosphere 2004, 55 (3), 395-400, DOI 10.1016/j.chemosphere.2003.11.010.

29. Lazar, R.; Edwards, R. C.; Metcalfe, C. D.; Metcalfe, T.; Gobas, F. A. P. C.; Haffner, G. substituted) polychlorinated biphenyls in environmental samples. Chemosphere 1992, 25 (4), 493-504, DOI 10.1016/0045-6535(92)90281-U.

30. Czamanski, M.; Nugraha, A.; Pondaven, P.; Lasbleiz, M.; Masson, A.; Caroff, N.; Bellail, R.; Treguer, P. Carbon, nitrogen and phosphorus elemental stoichiometry in

32. Beauchamp, K. C.; Collins, N.C.; Henderson, B.A. Covariation of growth and maturation of lake whitefish (Coregonus clupeaformis). J. Great Lakes Res. 2004, 30 (3), 451-460;

31. Ruetz, C. R.; Strouse, D. L.; Pothoven, S. A. Energy density of introduced round goby compared with four native fishes in a Lake Michigan tributary. T. Am. Fish. Soc. 2009, 138 (4), 938-947, DOI 10.1577/T08-048.1.

33. Paterson, G.; Whittle, D.M.; Drouillard, K.G.; Haffner, G.D. Declining lake trout (Salvelinus namaycush) energy density: are there too many salmonid predators in the Great Lakes? Can. J. Fish. Aq. Sci. 2009, 66 (6), 919-932; DOI: 10.1139/F09-048.

34. Elskus, A. A.; Stegeman, J. J.; Gooch, J. W.; Black, D. E.; Pruell, R. J. Polychlorinated biphenyl congener distributions in winter flounder as related to gender, spawning site, 
and congener metabolism. Environ. Sci. Technol. 1994, 28 (3), 401-407, DOI 10.1021/es00052a010.

35. Könemann, H.; van Leeuwen, K. Toxicokinetics in fish: Accumulation and elimination of six chlorobenzenes by guppies. Chemosphere. 1980, 9 (1), 3-19, DOI $\underline{10.1016 / 0045-}$ $\underline{6535(80) 90150-2}$ $\underline{6535(81) 90082-5 .}$.

37. Niimi, J.; Oliver, B. G. Biological half-lives of Polychlorinated Biphenyl (PCB) congeners in whole fish and muscle of rainbow-trout Salmo-Gairdneri. Can. J. Fish Aquat. Sci. 1983, 40 (9), 1388-1394, DOI 10.1139/f83-160

38. Paterson, G.; Drouillard, K. G.; Haffner, G. D. PCB elimination by yellow perch (Perca flavescens) during an annual temperature cycle. Environ. Sci. Technol. 2007, 41 (3), 824829, DOI 10.1021/es060266r.

39. Paterson G, Drouillard KG, Haffner GD (2007) Long-term polychlorinated biphenyl elimination by three size classes of yellow perch (Perca flavescens). Can. J. Fish. Aquat. Sci. 2007, 64 (9), 1222-1233, DOI 10.1021/es802567p and depuration of Polychlorinated biphenyls from field-collected sediment in three freshwater organisms. Environ. Sci. Technol. 2011, 45 (16), 7011-7018, DOI 10.1021/es1043744. 
41. Selck, H.; Drouillard, K.G.; Eisenreich, K.; Koelmans, A.A.; Palmqvist, A.; Ruus, A.; Salvito, D.; Schultz, I.; Stewart, R.; Weisbrod, A.; van den Brink, N.W.; van den HeuvelGreve, M. Explaining differences between bioaccumulation measurements in laboratory and field data through us of a probabilistic modeling approach. Integrated Environmental Assessment and Management, 2012, 8(1), 42-63; DOI: 10.1002/ieam.217.

42. McLeod, A.M.; Arnot, J.A.; Borga, K.; Selck, H.; Kashian, D.R.; Krause, A.; Paterson, G.; Haffner, G.D.; Drouillard, K.G. Quantifying uncertainty in the trophic magnification factor related to spatial movements of organisms in a food web. Integrated Environmental Assessment and Management, 2015, 11 (2), 306-318; DOI: 10.1002/ieam.1599.

43. Hebert, C.E.; Haffner, G.D. Habitat partitioning and contaminant exposure in cyprinids. Can. J. Fish. Aq. Sci. 1991, 48 (2), 261-266; DOI: 10.1139/f91-036.

44. McLeod, A.M.; Paterson, G.; Drouillard, K.G.; Haffner, G.D. Ecological factors contributing to variability of persistent organic pollutant bioaccumulation within forage fish communities of the Detroit River, Ontario, Canada. Environ. Toxicol. Chem. 2014, 33 (8), 1825-1831; DOI: 10.1002/etc.2606.

45. Kitchell, J.F.; Stewart, D. J., Weininger, D. Applications of a bioenergetics model to yellow perch (Perca flavescens) and walleye (Stizostedion vitreum vitreum). J. Fish. Res. Board Can. 1977, 34 (10) 1922-1935, DOI 10.1139/f77-258.

46. Riley, S. C. The State of Lake Huron in 2010. Great Lakes Fisheries Commission. 2010, 13-01.

47. Cha, Y.; Stow, C. A.; Nalepa, T. F.; Reckhowt, K. H. Do invasive mussels restrict offshore phosphorus transport in Lake Huron Watson, S.; Carpenter, D. Taking Action on Lake Erie. International Joint Commission. 2013. 
48. Brabrand, A.; Faafeng, B.A.; Petter, J.; Nilssen, M. Relative importance of phosphorus supply to phytoplankton production: fish excretion versus external loading. Can. J. Fish. Aquat. Sci, 1990, 47(2), 364-372, DOI 10.1139/f90-038.

49. Gresh, T.; Lichatowich, J.; Schoonmaker, P. An estimation of historic and current levels of salmon production in the northeast Pacific ecosystem: evidence of a nutrient deficit in the freshwater systems of the Pacific Northwest. Fisheries. 2000, 25 (1), 15-21, DOI 10.1577/1548-8446(2000)025<0015:AEOHAC>2.0.CO;2.

50. Gregory-Eaves, I. Demers, M. J.; Kimpe, L.; Krummel, E. M.; MacDonald, R. W.; Finney, B. P.; Blais, J. M. Tracing salmon-derived nutrients and contaminants in freshwater food webs across a pronounced spawner density gradient. Environ. Toxicol.

51. Lamarra, V. A. Digestive activities of carp as a major contributor to the nutrient loading of lakes. Verh. Int. Ver. Theor. Agnew. Limnol. 1975, 19, 2461-2468.

52. Carpenter, S. R.; Kraft, C. E.; Wright, R.; Xi, H.; Soranno, P. A.; Hodgson, J. R. Resilience and resistance of a lake phosphorus cycle before and after food web manipulation. Am. Nat. 1992, 140, 781-798, DOI 10.1086/285440. Vermont. J. Fish. Res. Board Can. 1975, 32 (10), 1785-1797. salmon populations in the U.S. waters of Lake Superior, 1981-1984. J. Great Lakes Res. 1986, 12 (1), 72-81, DOI $\underline{10.1016 / \mathrm{S} 0380-1330(86) 71701-2}$ 
55. Rand, P. S.; Stewart, D. J. Prey fish exploitation, salmonine production, and pelagic food web efficiency in Lake Ontario. Can. J. Fish. Aquat. Sci. 1998, 55 (2), 318-327, DOI 10.1139/cjfas-55-2-318.

56. Kitchell, J. F.; Cox, S. P.; Harvey, C. J.; Johnson, T. B.; Mason, D. M.; Schoen, K. K.; Aydin, K.; Bronte, C.; Ebener, M.; Hansen, M.; Hoff, M.; Schram, S.; Schreiner, D.; Walters, C. J. Sustainability of the Lake Superior fish community: interactions in a food

57. Kline Jr., T. C.; Goering, J. J.; Mathisen, O. A.; Poe, P. H.; Parker, P. L. Recycling of elements transported upstream by runs of Pacific Salmon: I. $\delta^{15} \mathrm{~N}$ and $\delta^{13} \mathrm{C}$ evidence in Sashin Creek, Southeastern Alaska. Can. J. Fish. Aquat. Sci. 1990, 47 (1), 136-144, DOI 10.1139/f90-014.

58. Kline Jr., T. C.; Goering, J. J.; Mathisen, O. A.; Poe, P. H.; Parker, P. L. Recycling of elements transported upstream by runs of Pacific Salmon: II. $\delta^{15} \mathrm{~N}$ and $\delta^{13} \mathrm{C}$ evidence in Kvichak River Watershed, Bristol Bay, Southwestern Alaska. Can. J. Fish. Aquat. Sci. 1993, 50 (11), 2350-2365, DOI 10.1139/f93-259.

59. Bilby, R. E.; Fransen, B. R.; Bisson, P. A. Incorporation of nitrogen and carbon from spawning coho salmon into the trophic system of small streams: evidence from stable isotopes. Can. J. Fish. Aquat. Sci. 1996, 53 (1), 164-173, DOI 10.1139/cjfas-53-1-164.

60. Cederholm, C. J.; Kunze, M. D.; Murota, T.; Sibatani, A. Pacific Salmon carcasses: Essential contributions of nutrients and energy for aquatic and terrestrial ecosystems. Fisheries 1999, 24 (10), 6-15, DOI 10.1577/1548-8446(1999)024<0006:PSC>2.0.CO;2. 
61. Jonsson, B.; Jonsson, N. Migratory Atlantic salmon as vectors for the transfer of energy and nutrients between freshwater and marine environments. Freshwater Biol. 2003, 48 (1), 21-27, DOI 10.1046/j.1365-2427.2003.00964.x.

62. Bunnell, D. B.; Barbiero, R. P.; Ludsin, S. A.; Madenjian, C. P.; Warren, G. J.; Dolan, D. M.; Brenden, T. O.; Briland, R.; Gorman, O. T.; He, J. X.; Johengen, T. H.; Lantry, B. F.; Lesht, B. M.; Nalepa, T. F.; Riley, S. C.; Riseng, C. M.; Treska, T. J.; Tsehaye, I.; Walsh, M. G.; Warner, D. M.; Weidl, B. C. (2014) Changing ecosystem dynamics in the Laurentian Great Lakes: Bottom-up and top-down regulation. Bioscience 2014, 64 (1), 26-39.

63. He, J. X.; Ebener, M. P.; Riley, S. C.; Cottrill, A.; Kowalski, A.; Koproski, S.; Mohr, L.; Johnson, J. E. Lake Trout status in the Main Basin of Lake Huron, 1973-2010. North 


\section{Supporting Information: PCB Food Web Dynamics}

598 Quantify Nutrient and Energy Flow in Aquatic

599 Ecosystems

600 AUTHOR NAMES. Anne M. McLeod*, Gordon Paterson, Ken G. Drouillard, G. Douglas

601 Haffner

602 AUTHOR ADDRESS. Great Lakes Institute for Environmental Research, University of

603 Windsor, Ontario, Canada N9B3P4. Correspondence to: mcleod15@uwindsor.ca, (519) 253-

6043000 ext 3752.

605

606 File consists of one supporting table and one supporting figure.

607 
608 Table S1.

609

\begin{tabular}{|c|c|c|c|}
\hline PCB & $\log \mathrm{K}_{\mathrm{Ow}}{ }^{\mathrm{a}, 21}$ & $\mathrm{E}_{\mathrm{d}, \mathrm{PCBi}} \mathrm{i}^{\mathrm{b}, 25}$ & $\mathrm{f}_{\mathrm{PCBi}}{ }^{\mathrm{c}, 24}$ \\
\hline $18 / 17$ & 5.1 & 0.802 & 0.96 \\
\hline $31 / 28$ & 5.67 & 0.699 & 0.71 \\
\hline 48 & 5.85 & 0.667 & 0.86 \\
\hline 44 & 5.75 & 0.685 & 0.86 \\
\hline 70 & 6.2 & 0.604 & 0.88 \\
\hline 99 & 6.39 & 0.570 & 0.93 \\
\hline 87 & 6.29 & 0.588 & 0.91 \\
\hline 110 & 6.48 & 0.554 & 0.93 \\
\hline 118 & 6.74 & 0.507 & 0.96 \\
\hline 153 & 6.85 & 0.487 & 0.96 \\
\hline $105 / 132$ & 6.7 & 0.514 & 0.91 \\
\hline 138 & 6.83 & 0.491 & 0.96 \\
\hline 158 & 7.02 & 0.456 & 0.97 \\
\hline 187 & 7.17 & 0.429 & 0.98 \\
\hline 183 & 7.2 & 0.424 & 0.97 \\
\hline 128 & 6.74 & 0.507 & 0.96 \\
\hline $156 / 171$ & 7.2 & 0.424 & 0.97 \\
\hline 180 & 7.36 & 0.395 & 0.98 \\
\hline 170 & 7.31 & 0.404 & 0.98 \\
\hline 201 & 7.2 & 0.424 & 0.985 \\
\hline $195 / 208$ & 7.65 & 0.343 & 0.983 \\
\hline 194 & 7.8 & 0.316 & 0.98 \\
\hline 206 & 8.09 & 0.264 & 0.989 \\
\hline 209 & 8.18 & 0.248 & 0.99 \\
\hline
\end{tabular}

610

611 a the octanol-water partition coefficient as reported in Hawker and Connell, 1988.

$612 \mathrm{~b}$ the organism`s assimilation efficiency of $\mathrm{PCB}_{\mathrm{i}}$ as reported in Liu et al. 2006.

$613{ }^{c}$ the fraction of $\mathrm{PCB}_{\mathrm{i}}$ accumulated from dietary sources as reported in Arnot and Gobas 2004.

614 


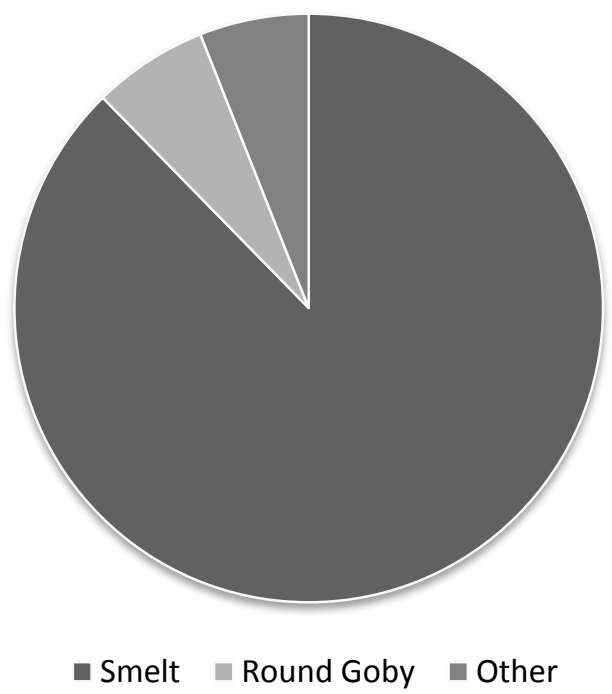

616

617 Figure S1. Results from gut content analyses on Lake Trout from Lake Huron. Proportions are 618 based on the number of each prey item obtained.

619

620

621 